\title{
POLA PENGGUNAAN ANTIBIOTIK PENYAKIT PNEUMONIA DI INSTALASI RAWAT INAP RUMAH SAKIT UMUM DAERAH ABDUL WAHAB SJAHRANIE
}

\author{
Fitri Ayu Wahyuni, Victoria Yulita Fitriani, Muhammad Amir Masruhim \\ Fakultas Farmasi Universitas Mulawarman, Samarinda, Kalimantan Timur \\ email : wahyunifitriayu@yahoo.co.id
}

\begin{abstract}
ABSTRAK
Pneumonia adalah penyakit batuk pilek disertai nafas sesak atau nafas cepat. Penyakit ini sering menyerang anak balita, namun juga dapat ditemukan pada orang dewasa dan pada orang usia lanjut. Pneumonia paling sering diakibatkan oleh infeksi bakteri, virus atau mikoplasma. Pemilihan dan penggunaan terapi antibiotika yang tepat dan rasional akan menentukan keberhasilan pengobatan. Selain itu tidak tertutup kemungkinan penggunaan antibiotik yang lain dapat meningkatkan peluang terjadinya Drug Related Problems (DRP). Tujuan penelitian ini adalah untuk mengetahui pola penggunaan antibiotik penyakit pneumonia pasien anak di instalasi rawat inap Rumah Sakit Abdul Wahab Sjahranie Kota Samarinda. Penelitian bersifat deskriptif, pengambilan data dilakukan secara retrospektif pada pasien pneumonia yang memenuhi kriteria inklusi. Data diambil pada periode bulan Januari-Desember 2014 melalui rekam medik. Hasil penelitian menunjukkan bahwa pasien pneumonia paling banyak diderita oleh laki-laki sebanyak 52 kasus $(63,42 \%)$ dan perempuan sebanyak 30 kasus $(36,58 \%)$, berdasarkan umur yang paling banyak berusia $1-12$ bulan sebanyak 49 pasien $(59,76 \%)$. Penggunaan antibiotik berdasarkan pemilihan golongan yang paling banyak digunakan adalah golongan sefalosporin generasi III sebanyak 41 pasien $(39,42 \%)$. Golongan penisilin sebanyak 22 pasien $(21,15 \%)$. Kombinasi antibiotik aminoglikosida dengan sefalosporin generasi III sebanyak sebanyak 11 pasien $(13,41 \%)$ dan kombinasi antibiotik penisilin dengan aminoglikosida sebanyak 11 pasien $(13,41 \%)$. Penggunaan antibiotik berdasarkan jenis obat yang paling banyak digunakan adalah sefotaksim sebanyak 31 pasien $(41,9 \%)$ dan ampisilin sebanyak 14 pasien (18,92\%). Sefiksim sebanyak 10 pasien (13,51\%) dan gentamisin sebanyak 10 pasien $(13,51 \%)$. Kombinasi antibiotik sefotaksim dengan gentamisin sebanyak 11 pasien $(13,41 \%)$ dan kombinasi antibiotik ampisilin dengan gentamisin sebanyak 11 pasien $(13,41 \%)$.
\end{abstract}

Kata Kunci : Pneumonia, antibiotik, anak, pola penggunaan

\begin{abstract}
Pneumonia is a disease cough, runny nose accompanied by shortness of breath or rapid breathing. This disease often affects children under five, but can also be found in adults and in the elderly. Pneumonia is most often caused by bacterial infections, viral or mycoplasma. Selection and use of appropriate antibiotic therapy and rational will determine the success of treatment. In addition it is also possible that another antibiotic use may increase the chances of Drug Related Problems (DRP). The purpose of this study was to determine the pattern of antibiotic use for pediatric patients pneumonia inpatient hospital Abdul Wahab Sjahranie Samarinda. The research is descriptive, retrospective data collection performed in pneumonia patients who met the inclusion criteria. Data taken
\end{abstract}


during the period from January to December 2014 through medical records. Results showed that patients with pneumonia most suffered by men as many as 52 cases $(63.42 \%)$ and women were 30 cases (36.58\%), based on the age of most aged 1-12 months in 49 patients $(59,76 \%)$. The use of antibiotics based on the selection of the most widely used class is the third generation cephalosporins were 41 patients $(39.42 \%)$. Penicillin group were 22 patients $(21.15 \%)$. Aminoglycoside antibiotic combination with the third generation cephalosporin as many as 11 patients (13.41\%) and combination with aminoglycoside antibiotics penicillin as many as 11 patients $(13.41 \%)$. The use of antibiotics based on the types of drugs most widely used is cefotaxime as many as 31 patients $(41.9 \%)$ and ampicillin total of 14 patients (18.92\%). Cefiksim as many as 10 patients (13.51\%) and gentamicin as many as 10 patients (13.51\%). Combination antibiotic cefotaxime with gentamicin as many as 11 patients $(13.41 \%)$ and the antibiotic combination of ampicillin with gentamicin as many as 11 patients $(13,41 \%)$.

Keywords: Pneumonia, antibiotics, children, usage patterns

\section{PENDAHULUAN}

Pneumonia adalah peradangan yang mengenai parenkim paru, distal dari bronkiolus respiratorius, dan alveoli, serta menimbulkan konsolidasi jaringan paru dan gangguan pertukaran gas setempat (Aru dkk, 2009).

Berdasarkan data WHO memperkirakan kejadian pneumonia di negara dengan angka kematian bayi di atas 40 per 1.000 kelahiran hidup adalah 15\% - 20\% pertahun pada golongan usia balita. Kejadian pneumonia di Indonesia pada balita diperkirakan antara 10\% sampai dengan 20\% pertahun (Sugihartono, 2012).

Riset kesehatan dasar Provinsi Kalimantan Timur Tahun 2007 prevalensi pneumonia di seluruh Kalimantan Timur adalah 1,42\%. Riset kesehatan dasar Provinsi Kalimantan Timur Tahun 2013 prevalensi pneumonia di seluruh Kalimantan Timur adalah $25 \%$ (DEPKES RI, 2013).

Berdasarkan prevalensi pneumonia yang semakin meningkat maka pemberian antibiotika juga semakin tinggi, salah satu indikator penggunaan obat yang tidak rasional di suatu sarana pelayanan kesehatan ialah angka penggunaan antibiotik (Pingkan,2013). Pemilihan dan penggunaan terapi antibiotika yang tepat dan rasional akan menentukan keberhasilan pengobatan. Beberapa dampak negatif penggunaan antibiotik meliputi pertumbuhan kuman yang resisten. Ketidaktepatan diagnosis, pemilihan obat, indikasi, dosis, cara pemberian dan frekuensi sering menjadi penyebab tidak akuratnya pengobatan. Sehubungan dengan beberapa uraian tersebut, penulis tertarik untuk melakukan penelitian dengan judul pola penggunaan antibiotik penyakit pneumonia di RSUD Abdul Wahab Sjahranie kota Samarinda.

\section{METODE PENELITIAN}

\section{Bahan}

Berkas rekam medik pasien pnumonia yang memenuhi kriteria inklusi, yang diperoleh dari 120 pasien pada Rumah Sakit Abdul Wahab Sjahranie Samarinda, Kalimantan Timur.

\section{Prosedur}

Penelitian diawali dengan observasi pasien pneumonia. Sampel ditentukan dari populasi pasien yang memenuhi kriteria inklusi. Kriteria inklusi sampel yaitu :

a. Pasien pneumonia rawat inap dengan diagnosa akhir pneumonia yang rekam mediknya lengkap dalam hal data penderita, data klinik dengan atau tanpa data laboratorium 
pendukung, dengan atau tanpa data laboratorium mikrobiologi, terapi obat meliputi jenis obat, dosis, rute pemberian aturan pakai dan lama pemakaian.

b. Pasien yang berumur 0-5 Tahun.

Penelitian ini dilakukan dengan pengambilan data secara retrospektif. Pengumpulan data dilakukan dengan mencatat beberapa parameter meliputi nomor rekam medik, umur, jenis kelamin, diagnosa, keluhan, riwayat penyakit dan penyakit penyerta. Data penelitian dianalisis secara deskriptif dan dihitung dengan perhitungan:

$\%$ Karateristik $=$ F/T $\times 100 \%$

Keterangan :

$\mathrm{F}=$ Frekuensi kejadian

$\mathrm{T}=$ Total populasi sampel

\section{HASIL DAN PEMBAHASAN}

Penelitian ini dilakukan di rumah sakit A. W. Sjahranie. Populasi penelitian diperoleh 120 pasien, terdiri dari pria dan wanita yang dirawat di instalasi rawat inap RSUD Abdul Wahab Sjahranie. Sampel pada penelitian ini sebanyak 82 rekam medik penderita pneumonia yang masuk dalam kriteria inklusi.



Gambar 1. Diagram Distribusi pasien anak dengan diagnosa pneumonia berdasarkan jenis kelamin

Gambar 1, menunjukkan diagram persentase kasus pneumonia secara keseluruhan pada anak berdasarkan jenis kelamin selama periode Januari-Desember 2014. Dari 82 kasus yang harus dirawat inap di RSUD Abdul Wahab Sjahranie sebanyak 63,42\% atau 52 kasus dialami oleh penderita anak laki-laki dan 36,58 \% atau 30 kasus dialami oleh penderita anak perempuan. Menurut beberapa penelitian sebelumnya diantaranya yang dilakukan oleh pingkan dkk di RSUP PROF. DR. R. D. KANDOU MANADO melaporkan bahwa karakteristik penderita pneumonia berdasarkan jenis kelamin lebih banyak pada laki-laki daripada perempuan (Pingkan,2013). Hasil penelitian ini diperkuat dengan Riset Kesehatan Dasar Tahun 2013 yang menyebutkan bahwa penderita pneumonia sebagian besar berjenis kelamin laki-laki (DEPKES RI, 2013).

Pneumonia lebih sering terjadi pada anak laki-laki berusia kurang dari 6 tahun. Hal ini mungkin berkaitan dengan dengan respon pada anak, karena secara biologis sistem pertahanan tubuh laki-laki dan perempuan berbeda. Organ paru pada perempuan memiliki daya hambat aliran udara yang lebih rendah dan daya hantar aliran udara yang lebih tinggi sehingga sirkulasi udara dalam rongga pernafasan lebih lancar dan paru terlindung dari infeksi patogen ( Uekert dkk,2006 ). 


$$
\begin{aligned}
& 0 \text { - } 1 \text { Bulan } \\
& 1 \text { - } 12 \text { Bulan } \\
& 1 \text { - } 3 \text { Tahun } \\
& -5 \text { - } 5 \text { Tahun }
\end{aligned}
$$

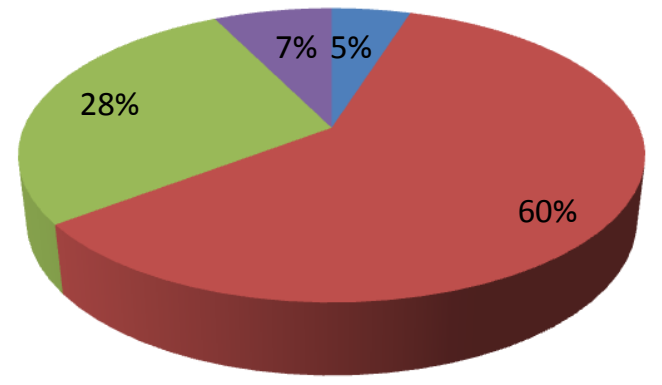

Gambar 2 Diagram Distribusi pasien anak pneumonia berdasarkan usia

Gambar 2, menunjukkan diagram persentase penderita berdasarkan umur diketahui jumlah penderita yang berumur 1-12 bulan menunjukkan presentase terbesar yaitu $59,76 \%$ ( 49 penderita ), umur 1-3 tahun $28,05 \%$ ( 23 penderita ), 3-5 tahun 7,31\% ( 6 penderita ) dan $0-1$ bulan $5 \%$ ( 4 penderita ).

Anak dengan kelompok usia kurang dari lima tahun rentan mengalami pneumonia berat dengan gejala batuk dan sukar bernafas. Sisterm kekebalan tubuh anak pada usia tersebut juga sangat rentan sehingga mudah terinfeksi oleh penyakit yang ditularkan melalui udara ( Misnadiarly, 2008).

\section{Penggunaan Antibiotik Pada Pneumonia}

Penggunaan antibiotik khususnya berkaitan dengan pengobatan penyakit infeksi. Penyakit pneumonia merupakan penyakit gangguan pada saluran pernafasan. Terapi antibiotik diperlukan dalam mengobati infeksi bakteri yang terjadi pada saluran pernafasan.

\section{Jenis dan golongan antibiotik yang Digunakan}

Tabel 1. Golongan antibiotik yang digunakan pada pasien anak penderita Pneumonia di instalasi Rawat Jalan RSUD Abdul Wahab Sjahranie

\begin{tabular}{llll}
\hline \multicolumn{1}{c}{ Komposisi } & \multicolumn{1}{c}{ Golongan Antibiotika } & Frekuensi & Persentase (\%) \\
\hline Tunggal & Sefalosporin Generasi III & 41 & 39,42 \\
& Penisilin & 22 & 21,15 \\
& Aminoglikosida & 7 & 6,73 \\
& Makrolida & 4 & 3,84 \\
\hline Kombinasi & Penisilin +Sefalosporin Generasi III & 2 & 1,92 \\
Dua & aminaglikosida +Sefalosporin Generasi & 11 & 10,57 \\
Antibiotika & III & & \\
& Penisilin +Aminoglikosida & 11 & 10,57 \\
& Sefalosporin Generasi III +Makrolida & 3 & 2,88 \\
& Aminoglikosida + Makrolida & 1 & 0,96 \\
& Penisilin +Makrolida & 1 & 0,96 \\
& Penisilin +Sefalosporin Generasi III & 1 & 0,96 \\
\hline Total & & 104 & 100 \\
\hline
\end{tabular}

Pada tabel 1, menunjukkan Persentase antibiotik tunggal, kombinasi dua antibiotik dan kombinasi tiga antibiotik pasien anak pneumonia yang dirawat di instalasi rawat inap RSUD Abdul Wahab Sjahranie. Antibiotik tunggal yang paling banyak digunakan adalah 
golongan antibiotik sefalosporin generasi III sebanyak 41 pasien $(39,42 \%)$ dan golongan antibiotik penisilin sebanyak 22 pasien $(21,15 \%)$. Kombinasi dua antibiotik yang paling banyak digunakan adalah kombinasi antibiotik golongan aminoglikosida dengan sefalosporin generasi III sebanyak 11 pasien $\quad(13,41 \%)$ dan golongan antibiotik penisilin dengan aminoglikosida sebanyak 11 pasien $(13,41 \%)$. Dari 82 total pasien anak penderita pneumonia terdapat 74 pasien anak yang menerima antibiotik tunggal diantaranya terdapat 10 pasien anak yang menerima 3 jenis antibiotik. Tujuan pemberian antibiotik lebih dari satu jenis yaitu untuk mengatasi infeksi campuran yang tidak dapat ditanggulangi oleh satu jenis antibiotik saja dan juga untuk meningkatkan aktivitas antibiotik pada infeksi spesifik.

Tabel 2. Jenis antibiotik tunggal yang digunakan pada pasien anak penderita Pneumonia di instalasi Rawat Jalan RSUD Abdul Wahab Sjahranie

\begin{tabular}{llll}
\hline Komposisi & Jenis Antibiotika & Frekuensi & Persentase (\%) \\
\hline Tunggal & Ampisilin & 14 & 18,92 \\
& Amoksisilin & 5 & 6,76 \\
& Sefiksim & 10 & 13,51 \\
& Sefotaksim & 31 & 41,90 \\
& Gentamisin & 10 & 13,51 \\
& Eritromisin & 4 & 5,40 \\
\hline & Total & 74 & 100
\end{tabular}

Tabel 2. Menunjukkan persentase jenis antibiotik tunggal yang digunakan pasien anak pneumonia yang di rawat diinstalasi rawat inap RSUD Abdul Wahab Sjahranie yang paling banyak digunakan adalah antibiotik golongan sefalosporin generasi III jenis cefotaksim sebanyak 31 pasien (41,90\%). Pengggunaan ampisilin sebanyak 14 pasien $(18,92 \%)$, penggunaan sefiksim sebanyak 10 pasien $(13,51 \%)$, gentamisin sebanyak 10 pasien $(13,51 \%)$, eritromisin sebanyak 4 pasien $(5,40 \%)$ dan amoksisilin sebanyak 5 pasien $(6,76 \%)$.

Tabel 3. Kombinasi dua antibiotik yang digunakan pada pasien anak penderita Pneumonia di instalasi Rawat Jalan RSUD Abdul Wahab Sjahranie

\begin{tabular}{|c|c|c|c|c|}
\hline Komposisi & & Jenis Antibiotika & Frekuensi & Persentase (\%) \\
\hline & & Ampisilin + Sefotaksim & 2 & 6,8 \\
\hline & & Sefotaksim + Gentamisin & 11 & 36,7 \\
\hline & & Ampisilin + Gentamisin & 11 & 36,7 \\
\hline & & Gentamisin + Sefiksim & 1 & 3,3 \\
\hline & & Sefriaxone + Gentamisin & 1 & 3,3 \\
\hline & & Gentamisin+ Eritromisin & 1 & 3,3 \\
\hline Kombinasi & Dua & Sefotaksim + Eritromisin & 1 & 3,3 \\
\hline Antibiotika & & Sefiksim + Eritromisin & 1 & 3,3 \\
\hline & & Ampisilin + Eritromisin & 1 & 3,3 \\
\hline Total & & & 30 & 100 \\
\hline
\end{tabular}

Pada tabel 3. Kombinasi dua antibiotika yang paling banyak digunakan adalah kombinasi cefotaksim dengan gentamisin sebanyak 11 pasien $(36,7 \%)$ dan juga kombinasi 
antibiotik ampisilin dengan gentamisin juga sebamyak 11 pasien $(36,7 \%)$. Pemberian kombinasi dua antibiotik tujuannya untuk memperluas spektrum aktifitas. Kombinasi ampisilin dengan gentamisin diberikan bila pasien dalam keadaan klinis berat seperti tidak dapat menyusui, makan dan minum, muntah, kejang dan tidak sadarkan diri sebagai alternatif bisa diberikan sefotaksim ( WHO, 2009).

Cara pemberian antibiotika pada penderita pneumonia anak yang dirawat inap di RSUD Abdul Wahab Sjahranie dilakukan melalui pemberian peroral maupun intravena. Antibiotik diberikan secara intravena pada pengobatan pneumonia karena pada kondisi berat, dimana penderita tidak dapat makan atau minum atau bahkan muntah sehingga pemberian antibiotika secara peroral tidaklah memungkinkan. Pemberian antibiotika secara intravena direkomendasikan pada ank-anak dengan pneumonia berat atau anak yang tidak bisa menerima antibiotika oral (Pingkan dkk, 2013). Penggantian pemberian antibiotika secara intravena ke antibiotika peroral dilakukan untuk pengobatan lanjutan pneumonia. Penggantian antibiotika intravena ke antibiotika oral dilakukan pada penderita dengan kondisi yang cukup stabil, dapat makan atau minum dan tidak muntah.

\section{KESIMPULAN}

Berdasarkan penelitian yang telah dilakukan maka dapat disimpulkan bahwa pasien pneumonia berdasarkan jenis kelamin yang paling banyak yaitu laki-laki sebanyak 52 kasus $(63,42 \%)$, perempuan 30 kasus $(36,58 \%)$, berdasarkan umur yang paling banyak berusia 1 - 12 bulan sebanyak 49 kasus $(59,76 \%)$. golongan dan jenis obat yang paling banyak digunakan adalah golongan sefalosporin generasi III sebanyak 41 pasien $(39,42 \%)$. Golongan penisilin sebanyak 22 pasien $(21,15 \%)$. Kombinasi antibiotik aminoglikosida dengan sefalosporin generasi III sebanyak sebanyak 11 pasien $(13,41 \%)$ dan kombinasi antibiotik penisilin dengan aminoglikosida sebanyak 11 pasien $(13,41 \%)$.

\section{DAFTAR PUSTAKA}

1. $\quad$ DEPKES RI. 2013. Riset Kesehatan Dasar (RISKESDA 2013): Badan Penelitian dan Pengembangan Kesehatan Kementerian Kesehatan RI Tahun 2013: Jakarta.

2. Misnadiarly. 2008. Penyakit Infeksi Saluran Napas Pneumonia pada Anak, Orang Dewasa, Usia Lanjut, Pneumonia atipik \& Pneumonia Atypik Mycobacterium Edisi 1. Pustaka Obor Populer. Jakarta

3. Pingkan C, Heedy Tjirosantoso, Paulina V.Y. Yamlean. 2014. Evaluasi Kerasionalan Penggunaan Antibiotik Pada Pengobatan Pneumonia Anak Di Instalasi Rawat Inap RSUP Prof. Dr. R. D. Kandou Manado Periode JanuariDesember 2013. PHARMACON Vol. 3 No 3.

4. Sudoyono A, Setiyohayadi, Alwi, Simadibrata K, Setiati. 2009. Ilmu Penyakit Dalam jilid III Edisi V. Interna Publishing. Jakarta.

5. Sugihartono.2012. Analisis Faktor Risiko Kejadian Pneumonia Pada Balita Di Wilayah Kerja Puskesmas Sidorejo Kota Pagar Alam.Jurnal Kesehatan Lingkungan Indonesia Vol. 11 No. 1.

6. Uekert, S.J. G. Akan. M. Evans. Z.Li. K. Roberg, C. Tisler, D. Dasilva, E. Anderson, R. Gangnon, D. B. Allen. 2006. Sex-Related Differences in Immune Development The Expression of Atopy in Early Chilhood. J Allergy Clin Immunol 118: 6: 1375-1381.

7. WHO. 2009. Pedoman Pelayanan Kesehatan anak Di Rumah Sakit. WHO press. Jakarta. 